\title{
IMPLEMENTASI PENGEMBANGAN \\ EKOWISATA BERBASIS MASYARAKAT \\ DI HUTAN LINDUNG GUNUNG SIRIMAU KOTA AMBON
}

\author{
Mersiana Sahureka ${ }^{1,}$ H.Lelloltery ${ }^{2}$, J.Ch. Hitipeuw ${ }^{3}$ \\ 1,2,3 Jurusan Kehutanan Fakultas Pertanian, Jln Ir.M.Putuhena, Kampus Poka- Ambon 97233 \\ ${ }^{*}$ Korespondensi Email: h_lellol@yahoo.com
}

Diterima : 8 Juli $2016 \quad$ Disetujui : 9 Oktober 2016

\begin{abstract}
Intisari
Tujuan umum yang ingin dicapai untuk mengetahui manfaat ekowisata bagi peningkatan kesejahtraan masyarakat dan konservasi sumberdaya alam di kawasan Hutan lindung Gunung Sirimau. Target khusus yang ingin dicapai adalah mengetahui strategi pengembangan ekowisata dengan menitikberatkan pada partisipasi masyarakat yang secara nyata melalui keikutsertaan masyarakat dalam seluruh kegiatan ekowisata mulai dari tahap perencanaan sampai evaluasi monitoring. Metode penelitian yang digunakan adalah metode survey dengan melakukan observasi, wawancara dan FGD antara kelompok sadar wisata, masyarakat dan pemerintah negeri Hukurila. FGD dilakukan dimodifikasi dari metode PRA (Baiquni, 2001) dengan proses meliputi perumusan masalah, identifikasi alternatif pemecahan masalah dan pelaksanaan kegiatan. Kerjasama dilakukan dengan stakeholder melalui pendekatan kemitraan. Data dianalisis diskriptif kualitatif untuk menggambarkan implimentasi pengembangan ekowisata berbasis masyarakat. Hasil penelitian menunjukkan bahwa kelompok sadar wisata "Sembilan" menjadi wadah/forum kelembagaan di desa pengelola ekowisata di Negeri Hukurila. Kegiatan yang dilakukan meliputi kegiatan masyarakat secara partisipatif dalam hal pengembalian keputusan, partisipasi dalam pelaksanaan kegiatan seperti pemandu wisata, penyedia jasa makanan serta minuman,pembersihan lingkungan lokasi wisata dan promosi wisata dan partisipasi serta penyedia dan pemeliharaan sarana prasarana wisata. Pendekatan kemitraan meliputi pengembangan SDM lokal seperti pelatihan pembuatan Website, kerjasama kelompok sadar wisata dengan organisasi masyarakat, penyuluhan dengan tema "Precious Hukurila" tentang pengenalan lingkungan sekitar. Kerjasama yayasan Heka Leka, YES (Youth Exchanges and Study Amerika), TPA Toisapu dan penyediaan fasilitas wisata seperti pembangunan Shelter dan rumah pertemuan di lokasi wisata pantai Tihulesy.
\end{abstract}

\begin{abstract}
Longterm goals to be achieved from this study was to determine the benefitts of ecotourism activities for the improvement of public welfare and conservation of natural resources in the protected forests of Mount Sirimau. Specific targets to be achieved is to know the tourism development strategy by focusing on real public participation through community participation in the entire ecotourism activities ranging from planning to evaluation monitoring.Metode research used survey method by observation, interviews and focus group discussions between groups of conscious travel, community and government Hukurila country. FGD conducted modified from the PRA method (Baiquni, 2001) with the process includes the formulation of the problem, identification of alternative problem-solving and implementation. Cooperation with stakeholders through a partnership approach. Data were analyzed qualitative descriptive to describe implimentasi community-based ecotourism development. The results showed that the group of tourism awareness "Nine" into institutional forum in the village who managed Hukurila ecotourism in the country. Activities include participatory community activities in terms of return decisions, participation in the implementation of activities such as a tour guide providers, providers of food and beverage services, environmental cleanup and promotion of tourist sites and providers of travel and participation and maintenance of facilities and infrastructure. While the partnership approach includes the development of local human resources such as training Website creatio cooperation aware group travel with community organizations, counseling with the theme "Precious Hukurila" about the introduction of the surrounding environment. Cooperation Foundation Heka Leka, YES (Youth Exchanges and Study USA).
\end{abstract}




\section{PENDAHULUAN}

\section{Latar Belakang}

Sumberdaya alam dan budaya di dalam kawasan-kawasan konservasi merupakan potensi besar yang dapat dimanfaatkan untuk pengembangan ekowisata. Kegiatan ekowisata di kawasankawasan konservasi seperti taman nasional, suaka margasatwa, cagar alam, taman wisata alam, taman hutan raya, taman buru dan hutan lindung telah memberikan manfaat besar bagi upaya konservasi lingkungan, ekonomi dan sosial (Nugroho Iwan, 2011). Hal ini disebabkan karena ekowisata tidak mengeksploitasi alam tetapi mengkonservasi dan memberi dampak bagi kesejahtraan masyarakat (Fandeli Chafid, 2000)

Salah satu bentuk ekowisata yang lebih spesifik yaitu ekowisata berbasis masyarakat. Masyarakat lokal memiliki kontrol terhadap pengembangan dan pengelolaan sehingga banyak memperoleh manfaat baik secara ekonomi, pendidikan, sosial, budaya, kesehatan maupun manfaat terhadap konservasi lingkungan alam. Ekowisata berbasis masyarakat merupakan pendekatan perencanaan pembangunan partisipasi alternatif yang bersifat partisipatif, dimana masyarakat secara aktif terlibat dalam kegiatan ekowisata dimaksud. Kegiatan ekowisata di kawasan konservasi seperti hutan lindung lebih menjadi minat wisatawan terutama mereka yang memilikikepedulian yang tinggi terhadap alam dan lingkungan.

Negeri Hukurila yang berada di sekitar hutan lindung gunung sirimau dapat menjadi destinasi wisata karena potensi wisata yang beragam. Potensi wisata alam meliputi potensi wisata bahari dengan panorama alam laut yang indah dengan goa bawah laut yang sudah menjadi destinasi untuk kegiatan diving di Kota Ambon. Beberapa potensi wisata pantai seperti pantai Tihulesi, pantai Wailirang, pantai Seu sedangkan air terjun "Eung" dalam hutan lindung juga menjadi destinasi wisata yang diminati. Potensi budaya meliputi upacara cuci negeri, tari cakalele, tari nyainyai dae, batu palungku dan kegiatan sasi juga merupakan atraksi wisata yang dapat menarik wisatawan berkunjung ke Negeri Hukurila. Namun saat ini prioritas pengembangan yaitu potensi wisata pantai, wisata bahari dan pemanfaatan landsekap pengunungan yang indah di bukit Tersili. Besarnya potensi wisata tersebut membutuhkan dukungan kelembagaan lokal guna pengelolaan yang lebih baik dan terencana.

Terbentuknya kelompok sadar wisata "Sembilan" sebagai wadah atau forum pengelolaan dan pengembangan ekowisata berbasis masyarakat di Negeri Hukurila telah mendorong upaya pemanfaatan potensi wisata, pemeliharaan kawasan dan perbaikan fasilitas wisata di lokasi wisata di Negeri Hukurila. Implementasi kegiatan wisata secara partisipatif yang dikoordinir oleh "kelompok sembilan" telah mendorong upaya pemeliharaan kawasan bersama masyarakat membuat tempattempat sampah yang ditempatkan di lokasi wisata pantai Tihulessy, kegiatan pembersihan sampah di pantai Tihulessi, serta dan pembuatan website Negeri Hukurila sebagai sarana promosi wisata melalui media elektornik dan brosur sebagai sarana promosi melalui media cetak untuk memperkenalkan potensi wisata Negeri Hukurila bagi dunia luar sehingga dapat mendorong peningkatan jumlah kunjungan wisatawan ke Negeri Hukurila.

Kelompok sadar wisata bersama pemerintah Negeri Hukurila telah membuat draf rencana pengelolaan dan pengembangan wisata yang memuat rencana pengelolaan dan pengembangan atraksi wisata, fasilitas dan aksesibilitas wisata serta action plan yang berisi rencana pengelolaan meliputi waktu kegiatan, uraian rencana kegiatan 
dan penanggung jawab kegiatan sehingga action plan tersebut menjadi panduan untuk implementasi kegiatan pengelolaan wisata di Negeri Hukurila.

Kelompok sadar wisata tidak bekerja sendiri tetapi bersama beberapa stakeholder membangun kerjasama untuk memajukan kegiatan wisata di Negeri Hukurila. Program pemberdayaan masyarakat dilakukan melalui kemitraan dengan stakeholder lainnya dalam hal ini kelompok sadar wisata "Sembilan" dengan Pemuda gereja Kota Ambon dengan melakukan pelatihan pembuatan website untuk promosi wisata melalui media elektronik. Kerjasama dengan yayasan Heka Leka dan TPA Toisapu dalam memberikan penyuluhan kepada anakanak dan diakhiri ini kegiatan pembersihan sampah di Pantai Tihulessi dengan melibatkan masyarakat.

Kegiatan yang berhubungan dengan promosi wisata ini dilakukan mengingat sampai saat ini potensi wisata di Negeri Hukurila yang beragam dan menarik namun belum banyak dikenal luas oleh masyarakat. Diharapkan dengan adanya promosi melalui media cetak dan elektronik ini dapat mendorong meningkatkan jumlah wisatawan mengunjungi objek-objek wisata di Negeri Hukurila.

\section{Tujuan Penelitian}

Penelitian ini dilaksanakan dengan tujuan 1) mengidentifikasi bentuk partisipasi masyarakat dalam kegiatan ekowisata di Negeri Hukurila, Kawasan Hutan Lindung Gunung Sirimau, 2) Menganalisis keterlibatan stakeholder dengan masyarakat dalam membangun kemitraan untuk pengembangan ekowisata di Negeri Hukurila.

\section{METODE PENELITIAN}

\section{Tempat dan Waktu Penelitian}

Penelitian dilaksanakan di Negeri Hukurila yang termasuk pada kawasan Hutan Lindung Gunung Sirimau Kecamatan Leitimur selatan Kota Ambon.

\section{Bahan dan Alat}

a. Bahan yang digunakan adalah masyarakat dan potensi objek wisata.

b. Alat yang digunakan adalah kamera, handycam, peta wilayah penelitian, alat tulis menulis

\section{Pelaksanaan Penelitian}

\section{(a) Jenis data yang dikumpulkan}

Data yang dikumpulkan berupa data primer dan sekunder. Data primer yang dikumpulkan meliputi: partisipasi masyarakat, aktivitas kelompok sadar wisata "Sembilan", Kegiatan stakeholder dalam mendukung kegiatan pengembangan wisata. Jenis data sekunder yang dikumpulkan meliputi: Keadaan umum lokasi sekitar dan data penunjang yang berhubungan dengan penelitian.

\section{(b) Teknik Pengumpulan Data}

Pengumpulan data diperoleh dengan cara pengamatan terlibat dengan mengikuti secara langsung bentuk keterlibatan masyarakat dalam kegiatan ekowisata. Data dikumpulkan dengan menggunakan metode:

1) Observasi, dilakukan melalui pengamatan interaksi sosial dalam masyarakat.

2) FGD (Focus Group Discussion) yang dimodifikasi dari metode PRA (Baiquni, 2001)

3) Studi Literatur, yang didasarkan atas laporanlaporan hasil penelitian, jurnal-jurnal, karya ilmiah dan sebagainya. Disamping itu juga dilakukan pencatatan pada data-data sekunder yang terdapat di instansi-instansi yang ada kaitannya dengan penelitian.

\section{Analisis Data}

Data yang diperoleh dianalisis dengan pendekatan kualitatif yaitu suatu teknik analisis untuk membuat gambaran mengenai suatu fenomena, menerangkan hubungan, menguji hipotesis serta mendapatkan implikasi dari suatu masalah yang diteliti (Nazir, 1988:64 dalam Tendy Kuhaja, 2014). Analisis kualitatif terhadap proses partisipasi masyarakat, dan proses kemitraan antara masyarakat (Kelompok sadar wisata "Sembilan") dan stakeholder yang terlibat dan mendukung kegiatan ekowisata di Negeri Hukurila.

Pada tahapan ini dilakukanimpelementasi strategi pengembangan ekowisata yang diperoleh dari tahap

I. Pada tahapan ini masyarakat dilibatkan secara partisipatif mulai dari perencanaan sampai monitoring dan evaluasi pelaksanaan kegiatan ekowisata. Selain itu juga dibangun kerjasama kemitraan antara masyarakat dan berbagai pihak. Adapun kegiatan yang dilakukan adalah sebagai berikut: 


\section{Partisipatif}

Pendekatan yang dapat digunakan untuk penyempurnaan suatu rencana pengembangan ekowisata melalui partisipatif dapat digunakan untuk pelaksanaan dan pemantauan serta evaluasi keberhasilan kegiatan pengembangan. Pendekatan partisipasi masyarakat dalam pengembangan ekowisata di kawasan hutan lindung gunung sirimau dapat dilihat pada tabel 1.

\section{Kerjasama Kemitraan}

Keberhasilan pengembangan ekowisata secara umummembutuhkanketerlibatanberbagaipihakdalam memberikan kontribusi yang konstruktif dari berbagai komponen yang ada, dan harus bertanggungjawab atas rencana pengembangan yang disusun. Oleh karena itu mengembangkan kerjasama kemitraan dari berbagai pihak (stakeholder) merupakan elemen penting untuk mencapai kesuksesan. Pedoman untuk membuat perencanaan dapat dilihat pada gambar berikut:

Tabel 1. Partisipasi Masyarakat dalam Pengembangan Ekowisata

\begin{tabular}{|c|c|c|c|}
\hline Pendekatan & Deskripsi & Teknik yang digunakan & $\begin{array}{l}\text { Pesan yang disampaikan } \\
\text { pada masyarakat }\end{array}$ \\
\hline $\begin{array}{l}\text { 1. Pendidikan atau } \\
\text { memberikan informasi } \\
\text { kepada masyarakat }\end{array}$ & $\begin{array}{l}\text { Memberikan pemahaman terha- } \\
\text { dap suatu keputusan }\end{array}$ & Penyuluhan, media massa & $\begin{array}{l}\text { Masyarakat mengerti ten- } \\
\text { tang ekowisata }\end{array}$ \\
\hline 2. Informasi balik & Pemahaman sebelum keputusan I & $\begin{array}{l}\text { Diskusi terfokus dengan kelom- } \\
\text { pok aspek tertentu }\end{array}$ & $\begin{array}{l}\text { Masyarakat mengerti dan } \\
\text { mendukung program }\end{array}$ \\
\hline 3. Konsultasi & $\begin{array}{l}\text { Memahami keinginan masyara- } \\
\text { kat dan terlibat dalam diskusi }\end{array}$ & $\begin{array}{l}\text { Pertemuan masyarakat dalam } \\
\text { rangka pemecahan masalah }\end{array}$ & $\begin{array}{l}\text { Memahami dan menghargai } \\
\text { saran masyarakat }\end{array}$ \\
\hline $\begin{array}{l}\text { 4.Mendorong keterliba- } \\
\text { tan masyarakat yang } \\
\text { lebih luas }\end{array}$ & $\begin{array}{l}\text { Mengetahui pengaruh terhadap } \\
\text { suatu keputusan itu, terhadap } \\
\text { masyarakat atau kelompok yang } \\
\text { lain }\end{array}$ & $\begin{array}{l}\text { Kelompok kerja, kelompok } \\
\text { pembimbing }\end{array}$ & $\begin{array}{l}\text { Dapat mempraktekan/me- } \\
\text { laksanakan saran masyara- } \\
\text { kat }\end{array}$ \\
\hline $\begin{array}{l}\text { 5.Rencana pengemban- } \\
\text { gan yang partisipatif }\end{array}$ & Menyetujui keputusan & Konsultasi, mediasi, negoisasi & $\begin{array}{l}\text { Berkomitmen penuh dalam } \\
\text { melaksanakan seluruh } \\
\text { keputusan }\end{array}$ \\
\hline
\end{tabular}

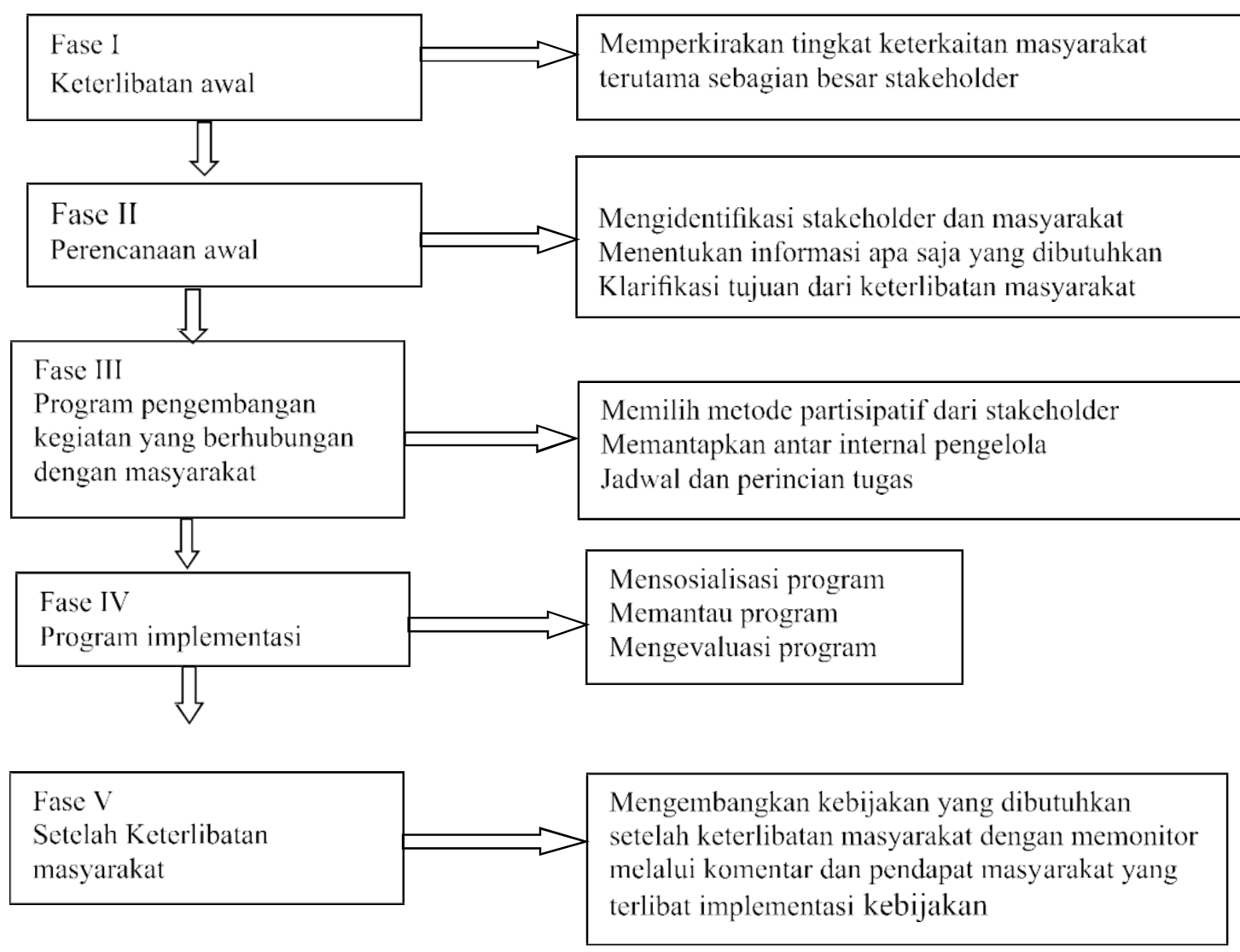


Dalam kerjasama kemitraan ini masingmasing pihak diberikan pemahaman tentang visi dan misi kegiatan ekowisata dalam kawasan konservasi termasuk hutan lindung, karena setiap kelompok mempunyai motivasi dan pandangan yang berbeda terhadap manfaat ekowisata di hutan lindung. Selanjutnya program-program pengembangan yang ada disinergikan dengan rencana induk pengembangan pariwisata kota Ambon.

\section{HASIL DAN PEMBAHASAN}

\section{Potensi Objek dan Daya Tarik Wisata di Negeri Hukurila.}

Hasil analisis terhadap ODTW menurut jenis wisata di Negeri Hukurila menunjukkan terdapat 5 jenis ODTW. Potensi wisata pantai alam menempati urutan pertama dengan $60 \%$, wisata budaya (20\%) dan wisata sejarah sebesar (20\%). Hasil analisis tersebut dapat dilihat pada tabel 2 .
Berdasarkan tabel 2 dapat dijeleskan bahwa potensi wisata alam memiliki ragam objek wisata yang tinggi, dikuti oleh wisata budaya dan sejarah. Hal ini jelas terlihat bahwa wisata alam menjadi modal untuk pengembangan ekowisata ke masa depan. Pemeliharaan objek-objek wisata alam dengan beragam atraksinya serta fasilitas wisata menjadi penting untuk dilakukan baik oleh masyarakat maupun juga dukungan dari stakeholder. Hal ini akan berdampak pada makin tingginya jumlah kunjungan wisatawan ke Negeri Hukurila dari waktu ke waktu.

\section{Bentuk Partisipasi Masyarakat dalam Kegiatan Ekowisata}

Partisipasi dapat dijadikan sebagai suatu instrumen untuk melakukan perubahan sosial, baik dalam arti proses maupun dalam arti output dari suatu kegiatan yang dilakukan. Partisipasi dapat diartikan sebagai bentuk keikutsertaan masyarakat dalam suatu kegiatan yang dilakukan. Keikutsertaan

Tabel 2. Persentase Potensi Jenis ODTW Menurut Jenis Wisata di Negeri Hukurila

\begin{tabular}{|c|c|c|c|}
\hline Potensi Wisata & Jenis ODTW & Nama ODTW & Jumlah \\
\hline \multirow[t]{6}{*}{ Wisata Alam } & \multirow[t]{3}{*}{ Wisata alam pantai } & -Pantai Tihulesi & $3(60 \%)$ \\
\hline & & -Pantai Wailurang & \\
\hline & & -Pantai Seu & \\
\hline & \multirow[t]{2}{*}{ Wisata Alam Bahari } & -Goa bawah laut & \\
\hline & & $\begin{array}{l}\text {-Terumbu karang dan beragam jenis } \\
\text { ikan }\end{array}$ & \\
\hline & $\begin{array}{l}\text { Wisata alam Tirta (Danau, air terjun, } \\
\text { permandian, mata air) }\end{array}$ & Air terjun "Eung" & \\
\hline Wisata sejarah & $\begin{array}{l}\text { Peninggalan, monument, benteng, } \\
\text { kuburan tua }\end{array}$ & \multicolumn{2}{|l|}{ Monumen Desa Hukurila } \\
\hline \multirow[t]{6}{*}{ Wisata budaya } & \multirow[t]{6}{*}{ Adat istiadat } & -Kearifan lokal (sasi dan dusung) & $1(20 \%)$ \\
\hline & & - Upacara cuci negeri & \\
\hline & & - acara adat silang kaki/masu minta & \\
\hline & & -Upacara lantik raja & \\
\hline & & -Tarian cakalele & \\
\hline & & -Tarian NyaiNyai Dae & \\
\hline
\end{tabular}


tersebut dapat diukur dari upaya-upaya memobilisasi masyarakat dalam suatu kegiatan. Berikut ini adalah berbagai bentuk partisipasi masyarkat dalam kegiatan pengembangan ekowisata di Negeri Hukurila :

a. Partisipasi dalam pengambilan keputusan pengembangan wisata.

- Penetapan lokasi prioritas pengembangan ekowisata yaitu di Gunung Tersili (dekat pintu masuk Negeri Hukurila) dan Pantai Tihulesy. Penetapan lokasi prioritas pengembangan ini didasarkan pada keunggulan objek wisata, pada gunung Tersili, memiliki pemandangan pegunungan dan hamparan laut dengan pantai pasir putih yang indah. Namun pada lokasi ini belum dilengkapi dengan berbagai fasilitas wisata dan jalan menuju lokasi objek. Lokasi wisata pantai Tihulesi di pilih sebagai lokasi pengembangan karena memiliki pasir putih, laut yang dangkal, pemandangan pantai dan hamparan laut yang indah. Lokasi ini telah dilengkapi dengan fasilitas wisata (Shelter, MCK, tempat samph, ruang pertemuan) sehingga akan menjadi lokasi yang dapat menampung berbagai aktifitas wisata di pantai.

b. Partisipasi dalam Pelaksanaan Kegiatan

- Penyedia jasa pemandu wisata

- Penyedia jasa makanan dan minuman

- Kegiatan dalam pembersihan lingkungan pada lokasi wisata pantai Tihulesy

- Promosi wisata lewat media cetak (brosur) dan elektronik (Website : www.hukurila.com) c. Partisipasi dalam penyedia fasilitas wisata dan aksesibilitas menuju lokasi objek wisata.

- Pembuatan dan pemeliharaan fasilitas wisata seperti shelter dan MCK di lokasi wisata pantai Tihulesi. Untuk melengkapi berbagai sarana prasarana wisata maka dalam rangka pengembangan ekowisata maka dapat dilakukan beberapa kegiatan seperti

- Pembangunan sarana dan prasarana di setiap lokasi objek wisata (Tempat Sampah, kamar ganti, pusat informasi, fasilitas kesehatan, tempat jualan, pos jaga). Terutama di pantai Wailurang, Pantai Seu, Bukit Tersili dan Air terjun "Eung".

- Papan Informasi Objek wisata di tempatkan pada lokasi strategis di dalam Negeeri sehingga menjadi petunjuk bagi wisatawan

- Toilet umum. Kerjasama dengan pemerintah desa dan instansi terkait untuk pembangunan toilet umum di lokasi objek maupun lokasi lain dalam desa.

- Tersedia klinik kesehatan atau puskesmas dalam Negeri sekitar objek wisata dalam mendukung aktivitas wisatawan.

Hubungan dengan masalah aksesibilitas maka diperlukan kerja keras dalam melakukan perbaikan atau pembersihan jalan-jalan setapak menuju lokasi objek wisata dan membuat tanda-tanda jalan untuk menunjukkan lokasi wisata yang akan dituju. Hal ini dimaksudkan sebagai petunjuk arah ke lokasi objek wisata.

d. Partisipasi dalam penyusunan draft Rencana Pengelolaan Ekowisata berbasis masyarakat
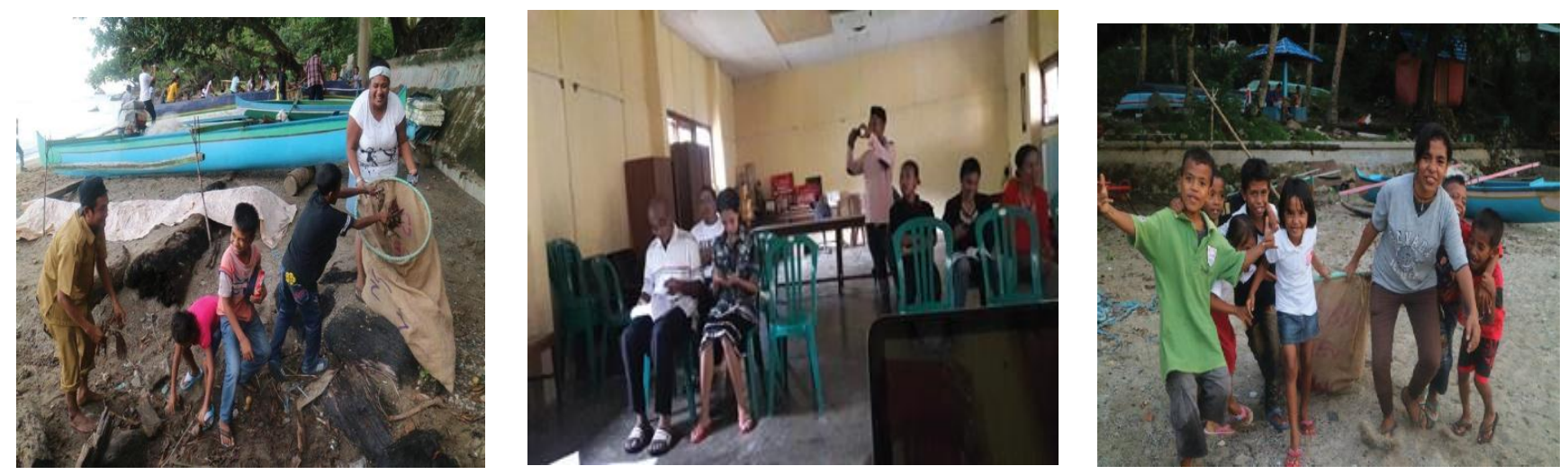

Gambar 1. Kegiatan Partisipasi Masyarakat dalam Kegiatan Ekowisata 

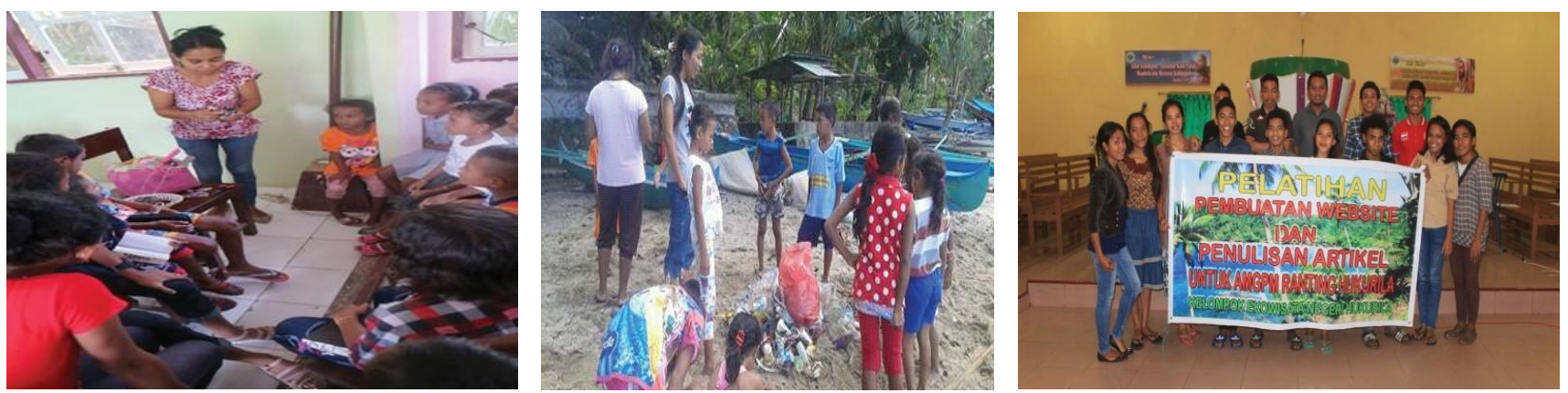

Gambar 2. Kegiatan Kemitraan di Negeri Hukurila

- Penyusunan draft pengelolaan dan pengembangan wisata di Negeri Hukurila yang berisi berbagai kegiatan dengan action plan yang tertata dan terjadwal dengan baik sehingga menjadi panduan dalam berbagai kegiatan wisata di Negeri Hukurila.

\subsection{Aktifitas Stakeholder dalam Ekowisata}

a. Pengembangan SDM lokal

- Kegiatan Pelatihan pembuatan Website, www.hukurila.com kerjasama kelompok sadar wisata dengan organisasi masyarakat.

- Penyuluhan dengan thema "Precious Hukurila" tentang pengenalan lingkungan sekitar. Kerjasama yayasan Heka Leka, YES (Youth Exchanges and Study Amerika), TPA Toisapu, kelompok sadar wisata "Sembilan", bersama pemerintah negeri Hukurila, SD Negeri Hukurila melakukan kegiatan pemberdayaan dengan membuat pelatihan mendaur ulang sampahsampah plastik kepada anak-anak. Hal ini maksudkan untuk membangun kecintaan dan kepedulian anak-anak terhadap alam lingkungan di sekitarnya.

b. Pemeliharaan Lingkungan

- Kegiatan pembersihan sampah dilokasi wisata pantai Tihulesy yang melibatkan masyarakat mulai dari anak-anak, pemuda dan orang dewasa. Kerja sama yayasan Heka Leka, YES (Youth Exchanges and Study Amerika), TPAToisapu c. Penyediaan Fasilitas Wisata

- Pembangunan Shelter dan rumah pertemuan di lokasi wisata pantai Tihulesy. Kerjasama IFAD dan masyarakat sekitar

d. Partisipasi dalam kegiatan evaluasi dan monitoring

- Pelaksanaan evaluasi kegiatan tiap 3 bulan sekali

\section{KESIMPULAN}

\section{Kesimpulan}

1. Kelompok sadar wisata "Sembilan" bersama pemerintah Negeri Hukurila terlibat dalam membuat rencana pengelolaan dan pengembangan ekowisata sebagai acuan dalam kegiatan wisata di Negeri Hukurila.

2. Kegiatan pemberdayaan masyarakat dilakukan melalui pembuatan brosur/Lea $\square$ et tentang potensi wisata di Negeri Hukurila

3. Pengembangan ekowisata di Negeri Hukurila dilakukan dengan pendekatan kemitraan antara kelompok sadar wisata dengan berbagai pihak seperti Yayasan heka-leka, TPA Toisupa, Yes Youth Axchanges and Studi America Kennedy serta Angkatan muda Negeri Hukurila.

4. Dalam rangka meningkatkan sumber daya manusia di Negeri Hukurila maka dilakukan pelatihan pembuatan Website www.hukurila. com hal ini dimaksudkan untuk melakukan dan meningkatkan promosi wisata di Negeri Hukurila sehingga dapat dikenal luas oleh masyarakat baik dalam dan luar negeri. 


\section{DAFTAR PUSTAKA}

Baiquni, M., 2001. Participatory Rural Appraisal. Pendekatan dan Metode Partisipasi Dalam Pengembangan Masyarakat.

Departemen Kehutanan.,1990. Undang-Undang No 5 Tahun 1990. Konservasi Sumberdaya Alam Hayati dan Ekosistemnya.

Departemen Kehutanan.,1999. Undang-Undang No 41 Tahun 1999, Tentang Kehutanan.

Fandeli, C., 2000. Pengusahaan Ekowisata. Penerbit Fakultas Kehutanan UGM.

Kuhaja, T., 2014. Kajian Kelembagaan dalam Pembangunan Pariwisata Pantai yang Berkelanjutan. Jurnal Pembangunan Wilayah dan Kota Volume 10(3): 278 - 292.

Nugraheni, E., 2002. Sistem Pengelolaan Ekowisata Berbasis Masyarakat di Taman Nasional (Studi Kasus Taman Nasional Gunung Halimun). Thesis.IPB
Nurfatriani,F dan Elvida YS, 2003. Pengelolaan Ekowisata Berbasis Masyarakat Lokal. Buletin Penelitian dan Pengembangan Kehutanan Vol. 4 No 1 tahun $2003: 21-30$.

Rangkuti, 2002., Analisis SWOT. Teknik Membedah

Kasus Bisnis. PT Gramedia Pustaka Utama Jakarta

The International Ecotourism Society, 2000. Ecotourism Statistical Fact Sheet.

Victor Kewilaa., 2013. Identifikasi dan Pengembangan Objek Wisata Negeri Soya Kecamatan Sirimau Kota Ambon (Tesis) Program Pasca Sarjana Program Studi Manajemen Hutan Universitas Pattimura

Wulandari dan Sumarti T., 2011. Implementasi Manajemen Kolaboratif dalam Pengelolaan Ekowisata Berbasis Masyarat. Jurnal Transdisiplin Sosiologi, Komunikasi dan Ekologi Manusia. Volume 06, No 01 (32-50). 